\title{
Multifaceted Microcephaly-Related Gene MCPH1
}

\author{
Martina Kristofova ${ }^{1}{ }^{\oplus}$, Alessandro Ori ${ }^{1}$ and Zhao-Qi Wang ${ }^{1,2, *}$ \\ 1 Leibniz Institute on Aging_Fritz Lipmann Institute (FLI), Beutenbergstrasse 11, 07745 Jena, Germany; \\ Martina.Kristofova@leibniz-fli.de (M.K.); Alessandro.Ori@leibniz-fli.de (A.O.) \\ 2 Faculty of Biological Sciences, Friedrich-Schiller University of Jena, Bachstrasse 18k, 07743 Jena, Germany \\ * Correspondence: zhao-qi.wang@leibniz-fli.de; Tel.: +49-3641-656415; Fax: +49-3641-656335
}

Citation: Kristofova, M.; Ori, A.;

Wang, Z.-Q. Multifaceted

Microcephaly-Related Gene MCPH1.

Cells 2022, 11, 275. https://doi.org/

10.3390/cells11020275

Academic Editor: Luisa Alexandra

Meireles Pinto

Received: 19 December 2021

Accepted: 12 January 2022

Published: 14 January 2022

Publisher's Note: MDPI stays neutral with regard to jurisdictional claims in published maps and institutional affiliations.

Copyright: (C) 2022 by the authors. Licensee MDPI, Basel, Switzerland. This article is an open access article distributed under the terms and conditions of the Creative Commons Attribution (CC BY) license (https:// creativecommons.org/licenses/by/ $4.0 /)$.

\begin{abstract}
MCPH1, or BRIT1, is often mutated in human primary microcephaly type 1, a neurodevelopmental disorder characterized by a smaller brain size at birth, due to its dysfunction in regulating the proliferation and self-renewal of neuroprogenitor cells. In the last 20 years or so, genetic and cellular studies have identified MCPH1 as a multifaceted protein in various cellular functions, including DNA damage signaling and repair, the regulation of chromosome condensation, cell-cycle progression, centrosome activity and the metabolism. Yet, genetic and animal model studies have revealed an unpredicted essential function of MPCH1 in gonad development and tumorigenesis, although the underlying mechanism remains elusive. These studies have begun to shed light on the role of MPCH1 in controlling various pathobiological processes of the disorder. Here, we summarize the biological functions of MCPH1, and lessons learnt from cellular and mouse models of MCPH1.
\end{abstract}

Keywords: MCPH; neurogenesis; gonad development; tumorigenesis; mouse models

\section{Neurogenesis and Brain Size Determination}

To ensure the development of the unusually large human brain to its size and complexity, highly precise mechanisms must govern temporal-spatial processes of the neuroprogenitor cells (NPCs) and their derivatives for their proliferation and differentiation. These processes have been extensively studied in the context of brain developmental disorders and in evolution. Brain size at birth is largely determined by the relative rate of proliferation and differentiation of NPCs during embryonic neurogenesis [1,2]. NPCs originate from the neuro-epithelium of the ventricular zone of the neural tube (dorsal telencephalon) [3,4]. During early neurogenesis, neuroepithelial cells initially proliferate to expand the progenitor pool, and later undergo differentiative divisions into daughter progenitors and neurons [5,6]. NPCs have an apical-basal polarity $[4,7]$ and their nuclei have the ability to move along the apical-basal axis (interkinetic nuclear migration), which is coordinated tightly by the cell cycle; yet, the reasons behind this are still debatable and unclear [8-10]. It is well established that NPCs' ability to proliferate has the main impact on brain size. Firstly, expansion of the neuroprogenitor pool is achieved via symmetric divisions ensuring their maintenance and self-renewal, to produce two identical cell types. On the other hand, asymmetric division produces one progenitor cell and one neuron. Finally, a specific type of symmetric division, i.e., symmetric differentiative division of NPCs, produces two daughter neurons.

Many factors influence which one of the division modes is favored and this process is tightly regulated. Among other factors, cell cycle length is one of the examples, with a longer G1 phase deciding for differentiation and a shorter one favoring self-renewal [11]. Interestingly, an experimentally shortened or prolonged G1 phase is sufficient to alter the division mode $[12,13]$. Another well-studied mechanism is related to the cell polarity. The relationship between the axis of cell polarity and the orientation of the cleavage plane (which is orthogonal to the mitotic spindle) is critical in deciding whether the cells undergo a symmetric or an asymmetric division [14,15]. According to this hypothesis, cell fate 
determinants are unequally distributed in the dividing parent cell. If the mitotic spindle orientation is parallel to the polar axis of the cell, the two daughter cells receive differential determinants and/or extracellular cues, resulting in an asymmetric division. On the other hand, when the polar axis and the mitotic spindle are in the perpendicular orientation, cells are more likely to divide symmetrically [16]. Therefore, the activity and function of the centrosome plays a critical role in these processes because the centrosome regulates spindle alignment, cilia formation, and the distribution of cell fate determinants during cell cycle progression [16]. In sum, the genetic and epigenetic factors that regulate the activity and function of all these cellular apparatuses are critical for neurogenesis and thereby determine brain size.

\section{Genetics and Etiology of Microcephaly (MCPH)}

Human primary microcephaly (MCPH, OMIM251200) is a neurodevelopmental disorder, characterized by a small brain at birth and clinically defined by a head circumference of more than three standard deviations below the mean compared to age-, sex-, and ethnicitymatched individuals [1,17]. The incidence of MCPH varies from 1:30,000 to 1:250,000 depending on the population and is generally high in populations in which consanguineous marriages are common $[17,18]$. Patients' IQ values are between $30 \%$ and $80 \%$ of the average of normal individuals, depending on the severity of the microcephaly [17]. The gross reduction in brain size mainly affects the prefrontal cortex, which otherwise exhibits a normal brain architecture, with all cortical layers developed. This suggests reduced cell divisions during neurogenesis [19] rather than neuronal cell death.

To date (13 January 2022), 29 loci (Table 1) have been identified as being causal for MCPH, with 28 loci listed in the Online Mendelian Inheritance in Man (OMIM) database (https: / / omim.org/entry/251200, accessed on 11 January 2022) [20,21], and it is likely that this list will grow in the future thanks to advances in "omics" methods, which enable better identification of disease-causing variants. The continuous expansion of the list clearly demonstrates a high genetic heterogeneity of $\mathrm{MCPH}$. Many of these genes have been implicated in various molecular and cellular processes, which contribute to the etiology of MCPHs. Strikingly, the vast majority of them play a role in centrosome function and mitotic spindle alignment [21,22]. The centrosome, as a major organizer of microtubules, is known to regulate the position and dynamics of the microtubule structure, such as the mitotic spindle alignment and cilia formation. Thus, primary microcephaly is often regarded as a form of ciliopathy, a group of diseases characterized by dysfunctional cilia [23-25]. During mammalian brain development, the centrosome controls the polarized cell behavior of neural cells from progenitor fate determination to neuronal migration and axonal growth navigation [24-26]. Hence, the maintenance of centrosome biogenesis, stability, and functionality is crucial for brain development, which nevertheless are very vulnerable to any pathological perturbations $[23,27]$.

Many recent reviews have already discussed other MCPH genes $[20,21,28]$. In this short article, we will focus on the MCPH1 gene, a founding member of the MCPH family, and summarize the genetic and molecular function of MPCH1.

Table 1. Genes associated with human MCPH (January 2022).

\begin{tabular}{|c|c|c|c|c|c|c|c|}
\hline Disease ID & $\begin{array}{c}\text { Chromosome } \\
\text { Location }\end{array}$ & Inheritance & Gene & Protein & $\begin{array}{l}\text { Subcellular } \\
\text { Location }\end{array}$ & Cellular Function & Reference \\
\hline МСРH1 & $8 \mathrm{p} 23.1$ & $\mathrm{AR}$ & МСРH1 & $\begin{array}{l}\text { Microcephalin 1/ } \\
\text { BRIT1 }\end{array}$ & $\begin{array}{l}\text { Nucleus/Centr } \\
\text { Mitochondria }\end{array}$ & $\begin{array}{l}\text { DNA damage } \\
\text { response, } \\
\text { chromatin } \\
\text { condensation, } \\
\text { cell cycle control }\end{array}$ & [29-33] \\
\hline МСРН2 & $19 q 13.12$ & $\mathrm{AR}$ & WDR62 & $\begin{array}{c}\text { WD } \\
\begin{array}{c}\text { Repeat-containing } \\
\text { protein } 62\end{array}\end{array}$ & $\begin{array}{l}\text { Centrosome/ } \\
\text { Spindle poles }\end{array}$ & $\begin{array}{c}\text { Centriole biogenesis, } \\
\text { spindle assembly }\end{array}$ & [34-37] \\
\hline
\end{tabular}


Table 1. Cont.

\begin{tabular}{|c|c|c|c|c|c|c|c|}
\hline Disease ID & $\begin{array}{l}\text { Chromosome } \\
\text { Location }\end{array}$ & Inheritance & Gene & Protein & $\begin{array}{l}\text { Subcellular } \\
\text { Location }\end{array}$ & Cellular Function & Reference \\
\hline МСРНЗ & $9 q 33.2$ & $\mathrm{AR}$ & CDK5RAP2 & $\begin{array}{l}\text { CDK5 regulatory } \\
\text { subunit-associated } \\
\text { protein } 2\end{array}$ & $\begin{array}{l}\text { Nucleus/ } \\
\text { Centrosome }\end{array}$ & $\begin{array}{l}\text { Centriole biogenesis, } \\
\text { spindle checkpoint, } \\
\text { cytokinesis }\end{array}$ & {$[38,39]$} \\
\hline МСРH4 & $15 q 15.1$ & $\mathrm{AR}$ & $\begin{array}{l}\text { CASC5 } \\
\text { (KNL1) }\end{array}$ & $\begin{array}{l}\text { Cancer } \\
\text { susceptibility } \\
\text { candidate } \\
5 / \text { Kinetochore } \\
\text { scaffold } 1 \\
\end{array}$ & Kinetochore & $\begin{array}{c}\text { Kinetochore } \\
\text { attachment } \\
\text { Spindle checkpoint }\end{array}$ & [40] \\
\hline МСРH5 & $1 \mathrm{q} 31.3$ & $\mathrm{AR}$ & ASPM & $\begin{array}{l}\text { Abnormal spindle } \\
\text { microtubule } \\
\text { assembly }\end{array}$ & $\begin{array}{l}\text { Nucleus/ } \\
\text { Centrosome/ } \\
\text { Midbody }\end{array}$ & $\begin{array}{l}\text { Centriole biogenesis, } \\
\text { spindle assembly, } \\
\text { cytokinesis }\end{array}$ & {$[35,41]$} \\
\hline МСРH6 & $\begin{array}{l}\text { 13q12.12- } \\
\text { q12.13 }\end{array}$ & $\mathrm{AR}$ & $\begin{array}{l}\text { CENPJ } \\
\text { (SAS-4, } \\
\text { CPAP) }\end{array}$ & $\begin{array}{c}\text { Centromere } \\
\text { protein } \mathrm{J}\end{array}$ & Centrosome & Centriole biogenesis & [38] \\
\hline МСРН7 & $1 \mathrm{p} 33$ & $\mathrm{AR}$ & STIL & $\begin{array}{c}\text { SCL/TAL1 } \\
\text { interrupting locus }\end{array}$ & Centrosome & $\begin{array}{l}\text { Centriole biogenesis, } \\
\text { spindle assembly }\end{array}$ & {$[42,43]$} \\
\hline МСРН8 & $4 q 12$ & $\mathrm{AR}$ & CEP135 & $\begin{array}{l}\text { Centrosomal } \\
\text { protein } 135\end{array}$ & Centrosome & Centriole biogenesis & {$[44,45]$} \\
\hline МСРН9 & $15 q 21.1$ & $\mathrm{AR}$ & CEP152 & $\begin{array}{l}\text { Centrosomal } \\
\text { protein } 152\end{array}$ & Centrosome & Centriole biogenesis & {$[39,46]$} \\
\hline МСРH10 & 20q13.12 & $\mathrm{AR}$ & ZNF335 & $\begin{array}{l}\text { Zinc finger protein } \\
335\end{array}$ & Nucleus & $\begin{array}{l}\text { Transcription, } \\
\text { chromatin } \\
\text { remodeling }\end{array}$ & [47] \\
\hline МСРH11 & $12 \mathrm{p} 13.31$ & $\mathrm{AR}$ & PHC1 & $\begin{array}{l}\text { Polyhomeotic- } \\
\text { like } 1\end{array}$ & Nucleus & $\begin{array}{l}\text { Transcription, } \\
\text { chromatin } \\
\text { remodeling }\end{array}$ & [48] \\
\hline МCPH12 & $7 q 21.2$ & $\mathrm{AR}$ & CDK6 & $\begin{array}{c}\text { Cyclin-dependent } \\
\text { kinase } 6\end{array}$ & $\begin{array}{c}\text { Cytosol/ } \\
\text { Nucleus/ } \\
\text { Centrosome/ } \\
\text { Spindle poles }\end{array}$ & Cell cycle & [49] \\
\hline МСРН13 & $4 q 24$ & $\mathrm{AR}$ & CENPE & $\begin{array}{c}\text { Centromere } \\
\text { protein E }\end{array}$ & Kinetochore & $\begin{array}{c}\text { Kinetochore } \\
\text { attachment, } \\
\text { spindle checkpoint } \\
\end{array}$ & {$[50]$} \\
\hline МСРH14 & $1 \mathrm{p} 21.2$ & $\mathrm{AR}$ & $\begin{array}{l}\text { SASS6 } \\
\text { (SAS6) }\end{array}$ & $\begin{array}{l}\text { Spindle assembly } \\
\text { abnormal protein } 6 \\
\text { homolog }\end{array}$ & Centrosome & Centriole biogenesis & {$[45,51]$} \\
\hline МСРH15 & $1 \mathrm{p} 34.2$ & $\mathrm{AR}$ & MFSD2A & $\begin{array}{l}\text { Major facilitator } \\
\text { superfamily } \\
\text { domain- } \\
\text { containing 2A }\end{array}$ & $\begin{array}{l}\text { Plasma } \\
\text { membrane }\end{array}$ & $\begin{array}{l}\text { Metabolism, cell } \\
\text { cycle }\end{array}$ & {$[52,53]$} \\
\hline МСРH16 & $12 q 24.33$ & $\mathrm{AR}$ & $\begin{array}{l}\text { ANKLE2 } \\
\text { (LEM4) }\end{array}$ & $\begin{array}{l}\text { Ankyrin repeat } \\
\text { and LEM domain- } \\
\text { containing } \\
\text { protein } 2\end{array}$ & $\begin{array}{l}\text { Endoplasmic } \\
\text { reticulum/ } \\
\text { Nucleus }\end{array}$ & $\begin{array}{l}\text { Nuclear envelope } \\
\text { assembly }\end{array}$ & [54] \\
\hline МСРH17 & $12 \mathrm{q} 24.23$ & $\mathrm{AR}$ & CIT & $\begin{array}{c}\text { Citron } \\
\text { rho-interacting } \\
\text { serine/threonine } \\
\text { kinase }\end{array}$ & $\begin{array}{l}\text { Spindle/ } \\
\text { Midbody }\end{array}$ & $\begin{array}{l}\text { Spindle assembly, } \\
\text { cytokinesis }\end{array}$ & {$[55,56]$} \\
\hline МСРH18 & $4 q 21.23$ & $\mathrm{AD}$ & $\begin{array}{c}\text { ALFY } \\
\text { (WDFY3) }\end{array}$ & $\begin{array}{l}\text { Autophagy-linked } \\
\text { FYVE protein }\end{array}$ & $\begin{array}{l}\text { Cytoplasm/ } \\
\text { Nucleus }\end{array}$ & Wnt signaling & [57] \\
\hline МСРН19 & $3 q 23$ & $\mathrm{AR}$ & COPB2 & $\begin{array}{l}\text { Coatomer protein } \\
\text { complex subunit } \\
\text { Beta } 2\end{array}$ & $\begin{array}{l}\text { Non-clathrin } \\
\text { vesicles }\end{array}$ & $\begin{array}{l}\text { Vesicle trafficking, } \\
\text { apoptosis }\end{array}$ & [58] \\
\hline МСРН20 & $1 \mathrm{q} 32.1$ & $\mathrm{AR}$ & KIF14 & $\begin{array}{l}\text { Kinesin family } \\
\text { member } 14\end{array}$ & $\begin{array}{l}\text { Spindle } \\
\text { poles / } \\
\text { Midbody }\end{array}$ & $\begin{array}{l}\text { Spindle assembly, } \\
\text { cytokinesis }\end{array}$ & {$[59,60]$} \\
\hline
\end{tabular}


Table 1. Cont.

\begin{tabular}{|c|c|c|c|c|c|c|c|}
\hline Disease ID & $\begin{array}{c}\text { Chromosome } \\
\text { Location }\end{array}$ & Inheritance & Gene & Protein & $\begin{array}{c}\text { Subcellular } \\
\text { Location }\end{array}$ & Cellular Function & Reference \\
\hline МСРН21 & 12 p13.31 & $\mathrm{AR}$ & $\begin{array}{l}\text { NCAPD2 } \\
\text { (CNAP1) }\end{array}$ & $\begin{array}{c}\text { Non-SMC } \\
\text { condensin I } \\
\text { complex subunit } \\
\text { D2/Centrosomal } \\
\text { Nek2-associated } \\
\text { protein } 1\end{array}$ & Nucleus & $\begin{array}{l}\text { Chromatin } \\
\text { condensation }\end{array}$ & [61] \\
\hline МСРН22 & $11 q 25$ & $\mathrm{AR}$ & NCAPD3 & $\begin{array}{c}\text { Non-SMC } \\
\text { condensin II } \\
\text { complex subunit } \\
\text { D3 }\end{array}$ & Nucleus & $\begin{array}{l}\text { Chromatin } \\
\text { condensation }\end{array}$ & [61] \\
\hline МСРН23 & $2 q 11.2$ & $\mathrm{AR}$ & NCAPH & $\begin{array}{c}\text { Non-SMC } \\
\text { condensin I } \\
\text { complex subunit H }\end{array}$ & Nucleus & $\begin{array}{l}\text { Chromatin } \\
\text { condensation }\end{array}$ & {$[61]$} \\
\hline МСРH24 & $12 \mathrm{q} 23.2$ & $\mathrm{AR}$ & NUP37 & Nucleoporin 37 & $\begin{array}{l}\text { Nucleus/ } \\
\text { Kinetochore }\end{array}$ & $\begin{array}{c}\text { Nuclear pore } \\
\text { assembly, } \\
\text { spindle assembly }\end{array}$ & [62] \\
\hline МСРН25 & $7 q 22.1$ & $\mathrm{AR}$ & $\begin{array}{l}\text { MAP11 } \\
\text { (TRAPPC14 }\end{array}$ & $\begin{array}{l}\text { Microtubule- } \\
\text { associated protein } \\
11\end{array}$ & $\begin{array}{l}\text { Spindle/ } \\
\text { Midbody / } \\
\text { Golgi }\end{array}$ & $\begin{array}{l}\text { Spindle assembly, } \\
\text { cytokinesis, Golgi } \\
\text { trafficking }\end{array}$ & [63] \\
\hline МСРН26 & $5 q 23.2$ & $\mathrm{AD}$ & LMNB1 & Lamin B1 & $\begin{array}{l}\text { Nucleus/ } \\
\text { Spindle }\end{array}$ & $\begin{array}{l}\text { Nuclear envelope } \\
\text { assembly, spindle } \\
\text { assembly }\end{array}$ & {$[64]$} \\
\hline МСРН27 & 19 p13.3 & $\mathrm{AD}$ & LMNB2 & Lamin B2 & $\begin{array}{l}\text { Nucleus/ } \\
\text { Spindle }\end{array}$ & $\begin{array}{c}\text { Nuclear envelope } \\
\text { assembly, spindle } \\
\text { assembly }\end{array}$ & {$[64]$} \\
\hline МСРН28 & $22 q 13$ & $\mathrm{AR}$ & RRP7A & $\begin{array}{c}\text { Ribosomal RNA } \\
\text { processing } 7 \\
\text { homolog A }\end{array}$ & Nucleolus & $\begin{array}{l}\text { Ribosome } \\
\text { biogenesis, primary } \\
\text { cilia resorption }\end{array}$ & {$[65]$} \\
\hline МСРН29 & $9 q 32$ & AR & AKNA & $\begin{array}{c}\text { AT-Hook } \\
\text { Transcription } \\
\text { Factor }\end{array}$ & Centrosome & $\begin{array}{l}\text { Microtubule } \\
\text { organization }\end{array}$ & [66] \\
\hline
\end{tabular}

$\mathrm{AR}$, autosomal recessive; $\mathrm{AD}$, autosomal dominant.

\section{Primary Microcephaly Type $1-\mathrm{MCPH1}$}

Primary microcephaly type 1 , historically also referred to as microcephalia vera, is the first discovered MCPH gene and is also allelic to the premature chromosome condensation syndrome (PCC, OMIM606858), characterized by a high proportion of prophase-like cells $[30,67]$. Another autosomal recessive condition of microcephaly associated with craniofacial abnormalities [68] was later found to be caused by mutations in the same MCPH1 gene [69]. Some MCPH1 patients also exhibit growth retardation, a feature typical of many "genetic instability disorders" caused by mutations in DNA repair proteins, such as the Seckel syndrome (caused by mutations in Ataxia-Telangiectasia and Rad3-related (ATR)) and the Nijmegen breakage syndrome (NBS, caused by mutation in NBS1, Nbn) [19]. The cause of the microcephaly phenotype in these genetic instability syndromes is believed to be attributed to the proliferation defects and apoptosis of NPCs during embryonic development [70]. Therefore, initially, microcephaly or MCPH1 was extensively studied for its role in the DNA damage response (DDR), including DNA repair, cell cycle checkpoint activation, apoptosis, and transcription $[19,71,72]$.

MCPH1 was the first locus identified as being responsible for MCPH1 [29,73] and is also one of the most commonly mutated genes, together with ASPM (MCPH5) and WDR62 (MCPH2) $[20,28,74]$. It is mapped to chromosome 8 [73] and the gene product was originally named Microcephalin [29]. It is also termed as BRIT1 (BRCT-repeat inhibitor of hTERT expression) because it was independently discovered in a genetic screen for regulators of the telomerase function [31], and later shown to be the same gene as MCPH1 [75]. 
Numerous MCPH1 mutations have been identified [76,77]. Notably, all missense mutations span the region of the N-terminal domain (exon 2 and 3), and result in non-conservative changes in amino acid residues. Amongst the most common patient mutations are nonsense $74 C>G$ mutations leading to the premature stop codon Ser25X $[17,29]$, or missense 80C $>G$ mutation leading to a Tyr27Arg substitution [78]. Some of the frequently mutated amino acids are evolutionary conserved, for example, Thr27, which is conserved in mammals and amphibians [78], and Ser72 and Trp75, which are conserved in all vertebrates and Drosophila [79].

\section{MCPH1 Protein Structure}

The MCPH1 gene is highly expressed in the human fetal brain, testis, liver, pancreas, and kidneys, yet at lower levels in other fetal and adult human tissues, such as the heart, lungs, thymus, and spleen $[29,80]$. In situ hybridization confirmed the expression in the developing forebrain in the region of the lateral ventricles, where NPC cells divide to produce neurons [81]. Expression of the Mcph1 gene in mice slightly declines after birth [81]. The MCPH1 protein comprises 14 exons (in both mouse and human), which span across 835 amino acids (aa) and $200 \mathrm{~kb}$ of genomic DNA. The MCPH1 protein exists in two major isoforms: the full-length MCPH1 (MCPH1-FL; 835aa) and the second one is expressed from an alternative transcript lacking the last six exons (MCPH1 $\mathrm{e}$ 9-14; 611aa). Both isoforms are expressed in fetal tissues at a similar level and have no cell type specificity [82]. Interestingly, both isoforms are regulated antagonistically during the cell cycle: MCPH1FL mRNA decreases from the mid-S phase to the G2 phase, while the transcript level of $\mathrm{MCPH} 1 \Delta \mathrm{e} 9-14$ increases during this period [82]. Additionally, both isoforms act differently in DDR, where only MCPH1-FL associates with ionizing radiation (IR)-induced foci (IRIF) of $\gamma \mathrm{H} 2 \mathrm{AX}$.

Structurally, MCPH1 contains three BRCT (BRCA C-terminal) domains, which were first described in BRCA proteins but can be found in many DDR proteins. Generally, these domains are 85-95 aa long with several conserved residues and often appear in repeats separated by variable linker regions no longer than 24 aa [83]. The structure of the BRCT domain is well characterized $[83,84]$, where a central $\beta$-sheet is surrounded by 2 or $3 \alpha$-helices [85]. It is a highly conserved structure since these domains are found besides Eukaryota in another two super kingdoms Archea and Bacteria [86]. The BRCT domain mediates protein-protein interactions, often specifically BRCT-BRCT interactions [87]. The BRCT repeats preferentially interact with phosphorylated proteins, for example, in the DDR cascade [84,88]. These motifs can also recognize ADP-ribosylation [89], which is important for DDR signaling. The first BRCT1 domain (2-83 aa) lies within the N-terminal region and the tandem of BRCT2 and BRCT3 spans the C-terminus (320-399 aa and 432-502 aa, respectively) of MCPH1. The tandem of BRCT2 and BRCT3 directs self-oligomerization and is crucial for IRIF formation [32,90]. Several studies reported that MCPH1 interaction with its partners is mediated by BRCT domains [76]. Intriguingly, it is the N-terminal BRCT domain that is decisive in MCPH1-associated phenotypes, including brain size [91,92]. A poorly conserved Condensin II-binding motif is located in the middle region. Although three distinct NLS were identified in the MCPH1 sequence, one in the N-terminus, one in exon 8 , and a third one in the BRCT3 in the C-terminus, the C-terminal NLS is responsible for nuclear localization [82]. In the middle domain, D-box (amino acids 752-755) and KEN-box (amino acids 599-601) degron (a short motif for degradation) sequences are found, which are recognized by the APC/C complex and mediate the degradation of MCPH1 in the G1 phase [93].

\section{Cellular Function of MCPH1}

\subsection{MCPH1 Subcellular Localization}

Co-localization of MCPH1 with $\gamma$-tubulin in U2OS cells suggests its putative centrosomal localization [94]. Similarly, ectopically expressed MCPH1 was found in the centrosome of human U2OS and chicken DT40 cells [32,95], which was attributed to its first BRCT 
domain in chicken cells [32], although other studies did not confirm the finding [90,96]. Indirect evidence of centrosomal localization was also obtained by experiments showing that the loss of MCPH1 leads to centrosome amplification and defective spindle assembly $[97,98]$. In response to DNA damage, MCPH1 forms IRIF and co-localizes with $\gamma \mathrm{H} 2 \mathrm{AX}$ in the nucleus [32]. Interestingly, immunofluorescence and electron microscopy of gold immunostaining revealed that $\mathrm{MCPH} 1$ is also associated with mitochondria in mouse and human NPCs [33].

\subsection{Cellular Toxicity}

It is known that the protein levels of MCPH1 are tightly regulated and prolonged overexpression of MCPH1 seems to be toxic to the cell $[96,99]$, although the reasons are unclear. Injecting Xenopus embryos with Mcph1 mRNA led to cell cycle arrest [96]. Some studies suggest a direct role of MCPH1 in apoptosis. For instance, MCPH1 overexpression in A549 lung carcinoma cells repressed uncontrolled cell proliferation via cell cycle arrest in the $S$ and G2/M phases [100]. In these cancer cells, MCPH1 overexpression promoted cell apoptosis due to an increase in the Bax and active caspase-3 protein levels, as well as a decrease in the level of Bcl-2 [100].

\subsection{MCPH1 and DNA Repair}

An aberrant DDR is characteristic of MCPH1 patient cells. MCPH1 is a surveillance protein that acts on DNA damage sites by recruiting sensor and mediator proteins $[75,101]$. In this regard, it facilitates homologous recombination repair (HRR) of double-strand breaks (DSBs) $[90,102]$. MCPH1 also recruits the BRCA2 and RAD51 complex at IRIF, presumably DSB sites, via a direct interaction between the C-terminus of MCPH1 and the N-terminal domain of BRCA2 [103]. Upon genotoxic stress and at the IRIF site, MCPH1 co-localizes with many proteins, including $\gamma \mathrm{H} 2 \mathrm{AX}$, mediator of DNA-damage checkpoint 1 (MDC1), p53-binding protein 1 (53BP1), ATM, ATR, CHK1, p-RAD17, and replication protein A (RPA34) [101,104,105]. Moreover, in response to UV radiation, the phosphorylation of RAD17 and RPA34, downstream effectors of the ATR pathway, is reduced in MCPH1deficient cells $[104,105]$. Under replicative stress, MCPH1 recruits TopBP1 and thereby facilitates ATR activation upon its phosphorylation at S322 by ATM or ATR [99].

In addition, the $\mathrm{N}$-terminal domain of MCPH1 can interact with the BAF170 subunit of the chromatin remodeling SWI/SNF complex to relax chromatin to allow DDR proteins to access DNA damage sites [80,106]. Its interaction with this complex is increased upon DNA damage in an ATR-dependent manner [106]. MCPH1 is associated with TRF2 at the telomere region [107] and this interaction allows homology-directed DNA repair and also promotes telomere replication during the S phase [108]. Consistently, MCPH1-deficient cells also show long telomeres, which is consistent with its telomerase-inhibiting role [109]. It was shown that MCPH1 is able to interact with the transcription factor E2F1 and is also involved in the transcriptional regulation of $\mathrm{CHK} 1$ and BRCA1, important proteins regulating cell cycle checkpoints in response to DNA damage [110]. Taken together, these studies demonstrate the important role of $\mathrm{MCPH} 1$ in regulating the DNA repair mechanisms and maintaining the genome integrity.

\subsection{MCPH1 and Cell Cycle Control}

MCPH1 has been described to regulate the activity of the cell cycle regulator CDC25A in an ATR-CHK1-dependent manner [71] and MCPH1 patient cells show a dysfunctional G2-M checkpoint mainly due to impaired degradation of CDC25A, causing premature entry into mitosis [71]. MCPH1 is also suggested to positively regulate some of the cell cycle checkpoint proteins, such as BRCA1 and CHK1, both being important for the G2/M transition $[75,111]$. MCPH1 via its centrosomal co-localization with $\mathrm{CHK} 1$ can directly interact with pericentrin [95]. The molecular mechanism by which MCPH1 regulates cell cycle progression was further demonstrated by its role in interacting with two E3 ubiquitin ligases: together with the $\beta \operatorname{TrCP} 2$ subunit of the SCF complex it regulates the S-phase pro- 
gression and G2-M transition [112], while it interacts with two subunits of APC/C, CDC27, and CDH1 in late mitosis in order to secure the entry of the G1 phase [112,113]. MCPH1 competes with Condensin II on chromatin [114] and the lack of MCPH1 promotes the binding of Condensin II to chromatin before all necessary mitotic structures are formed by the end of the G2 phase, ultimately leading to the PCC phenotype $[30,115]$. Hence, MCPH1 regulates the timely onset of mitosis, and it must be tightly regulated for degradation at the end of mitosis.

\subsection{Emerging Role of MCPH1 in Metabolism}

Recently, a role for MCPH1 in the regulation of mitochondrial activity and metabolism was reported [33], where MCPH1 directly interacts with VDAC1 and GRP75 in mouse and human NPCs to maintain glutaminolysis, a pathway involved in replenishing the tricarboxylic acid cycle and is vital for cell proliferation and survival $[116,117]$. Independently, in the proteomic screening of lipocalin-2 (LCN2)-deficient cells, which exhibited an altered mitochondrial function and fatty liver disease, MCPH1 was identified as a strongly downregulated protein [118]; however, it is unclear if this observation relates to its possible function at mitochondria or is a result of tumorigenesis in these mice. Further studies are required to assess the role of $\mathrm{MCPH} 1$ in the metabolic functions and its importance for NPCs' maintenance (Figure 1).

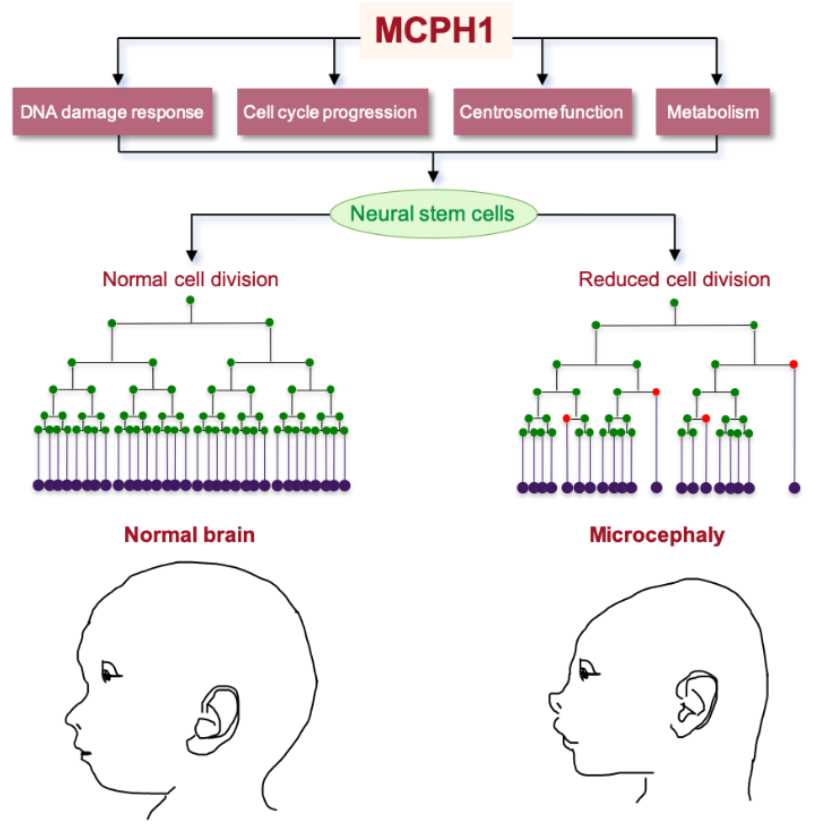

Figure 1. MCPH1 regulates brain size. MCPH1 is employed in many cellular functions that regulate the division mode of neural stem cells during embryonic brain development. Impairment of MCPH1 functions leads to an insufficient production of neurons (depicted in the diagram by dark purple dots) due to the premature differentiation of neural stem cells (depicted by red dots) and a reduction of self-renewal divisions (depicted by green dots). As a result, microcephaly manifests in affected individuals.

\section{Animal Models of MCPH1}

MCPH1 is implicated in a wide range of cellular processes as discussed above. However, the exact molecular mechanisms of how it regulates the expansion of the neuroprogenitor pool and thereby brain size still remains poorly understood. To better understand the role of MCPH1 in neurogenesis, several mouse models have been generated (Table 2). While some have mostly faithfully mimicked the brain and cellular phenotypes observed in human patients and patient cells, others have only recapitulated some phenotypes. In this regard, it is worth noting that MCPH1 has multiple structural domains, and each 
engages in different functions in vivo. It should also be mentioned that the mouse ortholog of MCPH1 shares only 57\% sequence homology with the human protein [29]. Below, we summarize all these studies.

\subsection{Mcph1-/- Mice}

The first Mcph1-null mouse model was generated via a Cre/LoxP-targeted deletion of exon 2 and showed no obvious microcephaly phenotype [105]. However, these mice were smaller, with a body weight of only $80 \%$ of their wild-type littermates. Unexpectedly, these mice exhibited infertility of both males and females accompanied by a reduction in the size of the gonads. Both $M c p h 1^{-/-}$mice and mouse embryonic fibroblasts (MEFs) isolated from them were hypersensitive to IR and had impaired mitotic and meiotic DDR signaling.

\subsection{Mcph1 ${ }^{g t / g t}$ Mice}

Another mouse model was generated by a gene trap approach, where the LacZ vector was inserted between exons 12 and 13, leading to a deletion of most of the C-terminal BRCT domain [111]. This mouse model is hypomorphic, since it still contained a residual MCPH1 protein and mutant mice had a normal brain and body weight, unaltered DDR, and were fertile. Interestingly, the mutant mice had significantly shorter lives than their littermate controls, and the mouse fibroblasts displayed a pronounced PCC phenotype. The PCC phenotype of Mcph1 ${ }^{g t / g t}$ mice that lack the C-terminal BRCT3 domain raises the point that perhaps the BRCT domain's ability to bind to phosphorylated proteins is implicated in the process of chromosome condensation, which is also accompanied by phosphorylated histones [119].

\subsection{Mcph1-del Mice}

The third and perhaps the most studied Mcph1 mutant mouse model was generated by a Cre/LoxP-targeted deletion of exon 4-5 [81]. Mcph1-del mutant mice had a smaller brain at birth, even already visible at E13.5, and showed growth retardation after birth [81]. The reduction in the brain size manifests predominantly in the cortical area while the cerebellum was not affected [120]. These mice also showed infertility and a reduction in the gonad size of the testes and ovaries [91]. The mutant mice exhibited an impaired DDR as judged by a hypersensitivity to IR [120]. In the NPCs derived from these mice, the localization of Chk1 to centrosomes is abrogated, causing premature $\mathrm{Cdk} 1$ activation and premature mitotic entry, which uncouples mitosis from the centrosome cycle [81]. By analyzing NPCs' cell cycle progression, a misalignment of chromosomes, lagging chromosomes, and deficient spindle checkpoint (multiple spindle poles) were observed in Mcph1-del mice [81]. As a result of the premature Cdk1 activation and the subsequent inadequate Cdc25a degradation, a shorter G2 phase was also reported, which leads to premature mitotic entry of NPCs [81]. Altogether, these molecular defects led to a premature switch from the symmetric to the asymmetric division mode and ultimately the exhaustion of the NPCs pool. Interestingly, overexpression of Chk1 in Mcph1-del mice failed to correct the microcephaly phenotype [77]. Notably, the expression of Chk1 is unaffected in human and murine MCPH1 cells [81,121]. It seems that Mcph1 does not regulate the expression of Chk1 but is directly or indirectly implicated in the regulation of its proper localization during the cell cycle. Moreover, Mcph1 also regulates the stability of Cdc25a by cooperation with E3 ligase $\beta$ TrCP2 in order to ensure proper timing of mitotic entry [112]. These observations strongly suggest that additional pathways are affected by the MCPH1 deletion.

\subsection{Mcph1 ${ }^{\text {tm1a/tm1a }}$ Mice}

Another hypomorphic Mcph1-deficient mouse model was generated by targeted deletion of exon 4 [122]. Mutant mice were infertile and had a reduced brain weight but without growth retardation. The defects in DNA damage repair were mild and only revealed by the increased prevalence of micronucleated normochromatic erythrocytes. Interestingly, 
this model showed an eye abnormality and hearing loss, which have not been reported in MCPH1 patients nor in other Mcph1-deficient mouse models.

Table 2. Summary of MCPH1 mouse models.

\begin{tabular}{|c|c|c|c|c|c|c|c|c|c|}
\hline \multirow[b]{2}{*}{$\begin{array}{l}\text { Mouse } \\
\text { Model }\end{array}$} & \multirow[b]{2}{*}{ Mutation } & \multicolumn{7}{|c|}{ Phenotypes } & \multirow[b]{2}{*}{ Reference } \\
\hline & & Microcephaly & $\begin{array}{c}\text { Smaller } \\
\text { Body }\end{array}$ & $\begin{array}{l}\text { Gonad } \\
\text { Atrophy }\end{array}$ & Infertility & Tumors & $\begin{array}{c}\text { DDR } \\
\text { Defects }\end{array}$ & PCC & \\
\hline$M c p h 1^{-1-}$ & $\begin{array}{c}\text { Exon } 2 \\
\text { deletion }\end{array}$ & No & Yes & Yes & Yes & No & Yes & NR & [105] \\
\hline$M c p h 1^{g t / g t}$ & $\begin{array}{l}\text { BRCT3 } \\
\text { deletion }\end{array}$ & No & No & No & No & No & No & Yes & [111] \\
\hline Mcph1-del & $\begin{array}{l}\text { Exon } 4-5 \\
\text { deletion }\end{array}$ & Yes & Yes & Yes & Yes & Yes & Yes & Yes & {$[81,120]$} \\
\hline$M c p h 1^{t m 1 a / t m 1 a}$ & $\begin{array}{c}\text { Exon } 4 \\
\text { deletion }\end{array}$ & Yes & No & NR & Yes & NR & Yes & NR & [122] \\
\hline Mcph1- $\Delta B R 1$ & $\begin{array}{c}\text { BRCT1 } \\
\text { deletion }\end{array}$ & Yes & Yes & Yes & Yes & Yes & Yes & Yes & [91] \\
\hline
\end{tabular}

Note: DDR, DNA damage response; PCC, premature chromosome condensation; NR: not reported.

\subsection{Mcph1 $1^{\text {lox/lox }} ; \operatorname{Emx} 1^{\text {kiCre/+ }}$}

In this conditional mouse model, Mcph1 was inactivated specifically in the neocortical progenitors in the lateral neocortex of E12.5 embryos [33]. These mice developed microcephaly due to the mitotic anomalies associated with increased apoptosis in the neocortex. Mutant NPCs harbored fragmented mitochondria and decreased the ATPase activity. The authors demonstrated a direct interaction of Mcph1 with VDAC1 in NPCs, which stimulates glutaminolysis via the ATF4/PCK2 pathway. This study, for the first time, links Mcph1 with the metabolic pathways to secure the energetic supply for highly proliferating NPCs.

\subsection{Mcph1- $\triangle B R 1$ Mice}

With the notion of the fact that mutations in human MCPH1 patients are mostly in the N-terminal domain of Mcph1, Mcph1- $\triangle B R 1$ mice were generated by a targeted deletion of the N-terminal BRCT1 domain [91]. Remarkably, these mutant mice sufficiently recapitulate all core phenotypes of complete knockout mice, such as microcephaly, infertility, PCC, and impaired DDR $[81,105,120]$. These observations strongly indicate the important role of the N-terminal BRCT domain in the etiology of MCPH1 and the brain size determination [91,92]. However, open questions remain as to how the N-terminal BRCT would influence brain development: (1) what is the contribution of other domains of the protein, and (2) what are those to-be-identified BRCT1-protein interaction partners, which would make the final decision regarding brain size.

Strikingly, infertility has been observed in several Mcph1-deficient mouse models, which is accompanied by atrophy of gonads, i.e., testes and ovaries, as well as tumorigenesis in these organs $[81,91,105]$. Thus, it is plausible that MCPH1's role in maintaining a big brain and gonad development is important for positive selection in the primate lineage during evolution $[123,124]$. The high tumor penetrance in Mcph1 mutant mice is also interesting, which is consistent with the observation that MCPH1 was found to be mutated in many malignancies, including breast, ovarian, and prostate cancer $[125,126]$. Many functions of MCPH1 can be attributed to tumorigenesis, for example, MCPH1's role in DDR and cell cycle checkpoint activation, as well as in the maintenance of genome integrity. MCPH1 is also responsible for centrosome amplification [98], which is a common hallmark of many cancers.

Despite consistent phenotypes of impaired gonad development, infertility, and tumorigenesis in various MCPH1 mouse models [91,105,122], MPCH1 patients have not yet been reported for these symptoms. Some of the Mcph1-deficient mice have been reported to have a short lifespan [111,127], whereas other models did not display a short 
lifespan [81,91,122]. There is no systematic report on lifespan in MCPH1 patients, but one study reports MCPH1 patients in their $70 \mathrm{~s}$ [74]. In sum, the mouse model studies demonstrate a multifaced function of MCPH1 in various pathophysiological processes, even beyond brain development.

Finally, it is interesting to mention that transgenic rhesus monkeys overexpressing the human copy of the MCPH1 gene (huMcph1-Tg monkeys) showed a relative greater brain volume compared to non-transgenic control monkeys during early postnatal development [128]. Interestingly, these transgenic monkeys seem to have improved cognitive functions, i.e., short-term memory, although they had delayed neuronal maturation and differentiation [128].

\section{Perspectives}

MCPH1 plays pleiotropic roles in DDR, cell cycle progression and centrosome function, spindle alignment, chromatin remodeling, and metabolism. The MCPH1 gene is ubiquitously expressed in tissues but, strikingly, only a limited number of cellular compartments, i.e., neuro-stem cells, and perhaps also primary germ cells, are particularly vulnerable to the mutation or loss-of-function of MCPH1. This high tissue specificity remains mysterious. It is possible that these tissue-specific stem cells are not equipped with alternative pathways to cope with any perturbations of the mechanisms elicited by MCPH1 loss. Or in parallel to this hypothesis, different functional domains of the MCPH1 protein can engage with different partners in a temporal-spatial manner under physiological and pathological conditions. Therefore, searching for partners that interact with different domains would be beneficial for understanding the specific as well as diverse functions of MCPH1. Finally, the dissection and understanding of the causal mutations in human MCPH1 using more robust and feasible model systems, which even closely reassemble human patients, such as human or primate brain organoids, may provide insight into the etiology of microcephaly and cognitive disorders.

Author Contributions: M.K., A.O. and Z.-Q.W. contributed to the writing of the manuscript. All authors have read and agreed to the published version of the manuscript.

Funding: The project has been supported by the DFG grants of Germany to Z.-Q.W. (WA2627/2-1, WA2627/2-2). The authors declare no competing interests.

Acknowledgments: There is a huge number of excellent papers published by many laboratories in the field of MCPHs. We apologize for those whose work could not be discussed due to the focused theme and limited space allowed in this short manuscript. We are grateful to Tatiana Kamaletdinova for her contribution to the realization of Graphic Abstract. We thank Eileen Stoeckl for editing the manuscript. We also thank members of the Wang laboratory for their critical and helpful discussions. M.K. is a doctoral candidate of the Leibniz Gradual School on Aging (LGSA) at the FLI. We are grateful to the DFG grants of Germany to Z.-Q.W. (WA2627/2-1, WA2627/2-2) to support our research.

Conflicts of Interest: The authors declare no conflict of interest.

\section{References}

1. Kaindl, A.M.; Passemard, S.; Kumar, P.; Kraemer, N.; Issa, L.; Zwirner, A.; Gerard, B.; Verloes, A.; Mani, S.; Gressens, P. Many roads lead to primary autosomal recessive microcephaly. Prog. Neurobiol. 2010, 90, 363-383. [CrossRef] [PubMed]

2. Ryu, J.R.; Hong, C.J.; Kim, J.Y.; Kim, E.K.; Sun, W.; Yu, S.W. Control of adult neurogenesis by programmed cell death in the mammalian brain. Mol. Brain 2016, 9, 43. [CrossRef] [PubMed]

3. Gotz, M.; Huttner, W.B. The cell biology of neurogenesis. Nat. Rev. Mol. Cell Biol. 2005, 6, 777-788. [CrossRef] [PubMed]

4. Hakanen, J.; Ruiz-Reig, N.; Tissir, F. Linking Cell Polarity to Cortical Development and Malformations. Front. Cell Neurosci. 2019, 13, 244. [CrossRef]

5. Paridaen, J.T.; Huttner, W.B. Neurogenesis during development of the vertebrate central nervous system. EMBO Rep. 2014, 15, 351-364. [CrossRef]

6. Bonnefont, J.; Vanderhaeghen, P. Neuronal fate acquisition and specification: Time for a change. Curr. Opin. Neurobiol. 2021, 66, 195-204. [CrossRef]

7. Chenn, A.; Zhang, Y.A.; Chang, B.T.; McConnell, S.K. Intrinsic polarity of mammalian neuroepithelial cells. Mol. Cell Neurosci. 1998, 11, 183-193. [CrossRef] 
8. Sauer, F.C. Mitosis in the neural tube and the cellular structure of the neural tube. Philadelphia 1935, 377-405, 313-323.

9. Kosodo, Y. Interkinetic nuclear migration: Beyond a hallmark of neurogenesis. Cell Mol. Life Sci. 2012, 69, 2727-2738. [CrossRef]

10. Molina, A.; Pituello, F. Playing with the cell cycle to build the spinal cord. Dev. Biol. 2017, 432, 14-23. [CrossRef]

11. Cheffer, A.; Tarnok, A.; Ulrich, H. Cell cycle regulation during neurogenesis in the embryonic and adult brain. Stem Cell Rev. Rep. 2013, 9, 794-805. [CrossRef]

12. Lange, C.; Huttner, W.B.; Calegari, F. Cdk4/cyclinD1 overexpression in neural stem cells shortens G1, delays neurogenesis, and promotes the generation and expansion of basal progenitors. Cell Stem Cell 2009, 5, 320-331. [CrossRef] [PubMed]

13. Pilaz, L.J.; Patti, D.; Marcy, G.; Ollier, E.; Pfister, S.; Douglas, R.J.; Betizeau, M.; Gautier, E.; Cortay, V.; Doerflinger, N.; et al. Forced G1-phase reduction alters mode of division, neuron number, and laminar phenotype in the cerebral cortex. Proc. Natl. Acad. Sci. USA 2009, 106, 21924-21929. [CrossRef] [PubMed]

14. Vargas-Hurtado, D.; Brault, J.B.; Piolot, T.; Leconte, L.; Da Silva, N.; Pennetier, C.; Baffet, A.; Marthiens, V.; Basto, R. Differences in Mitotic Spindle Architecture in Mammalian Neural Stem Cells Influence Mitotic Accuracy during Brain Development. Curr. Biol. 2019, 29, 2993-3005. [CrossRef]

15. di Pietro, F.; Echard, A.; Morin, X. Regulation of mitotic spindle orientation: An integrated view. EMBO Rep. 2016, 17, 1106-1130. [CrossRef] [PubMed]

16. Matsuzaki, F.; Shitamukai, A. Cell Division Modes and Cleavage Planes of Neural Progenitors during Mammalian Cortical Development. Cold Spring Harb. Perspect. Biol. 2015, 7, a015719. [CrossRef]

17. Woods, C.G.; Bond, J.; Enard, W. Autosomal recessive primary microcephaly (MCPH): A review of clinical, molecular, and evolutionary findings. Am. J. Hum. Genet. 2005, 76, 717-728. [CrossRef]

18. Kumar, A.; Markandaya, M.; Girimaji, S.C. Primary microcephaly: Microcephalin and ASPM determine the size of the human brain. J. Biosci. 2002, 27, 629-632. [CrossRef]

19. O'Driscoll, M.; Jackson, A.P.; Jeggo, P.A. Microcephalin: A causal link between impaired damage response signalling and microcephaly. Cell Cycle 2006, 5, 2339-2344. [CrossRef] [PubMed]

20. Siskos, N.; Stylianopoulou, E.; Skavdis, G.; Grigoriou, M.E. Molecular Genetics of Microcephaly Primary Hereditary: An Overview. Brain Sci. 2021, 11, 581. [CrossRef]

21. Jean, F.; Stuart, A.; Tarailo-Graovac, M. Dissecting the Genetic and Etiological Causes of Primary Microcephaly. Front. Neurol. 2020, 11, 570830. [CrossRef] [PubMed]

22. Bond, J.; Woods, C.G. Cytoskeletal genes regulating brain size. Curr. Opin. Cell Biol. 2006, 18, 95-101. [CrossRef]

23. Thomas, S.; Boutaud, L.; Reilly, M.L.; Benmerah, A. Cilia in hereditary cerebral anomalies. Biol. Cell 2019, 111, 217-231. [CrossRef] [PubMed]

24. Joukov, V.; De Nicolo, A. The Centrosome and the Primary Cilium: The Yin and Yang of a Hybrid Organelle. Cells $2019,8,701$. [CrossRef]

25. Andreu-Cervera, A.; Catala, M.; Schneider-Maunoury, S. Cilia, ciliopathies and hedgehog-related forebrain developmental disorders. Neurobiol. Dis. 2021, 150, 105236. [CrossRef] [PubMed]

26. Bornens, M. Cell polarity: Having and making sense of direction-on the evolutionary significance of the primary cilium/centrosome organ in Metazoa. Open Biol. 2018, 8. [CrossRef]

27. Nulty, J.; Alsaffar, M.; Barry, D. Radial glial cells organize the central nervous system via microtubule dependant processes. Brain Res. 2015, 1625, 171-179. [CrossRef] [PubMed]

28. Jayaraman, D.; Bae, B.I.; Walsh, C.A. The Genetics of Primary Microcephaly. Annu. Rev. Genom. Hum. Genet. 2018, 19, 177-200. [CrossRef]

29. Jackson, A.P.; Eastwood, H.; Bell, S.M.; Adu, J.; Toomes, C.; Carr, I.M.; Roberts, E.; Hampshire, D.J.; Crow, Y.J.; Mighell, A.J.; et al. Identification of microcephalin, a protein implicated in determining the size of the human brain. Am. J. Hum. Genet. 2002, 71, 136-142. [CrossRef]

30. Trimborn, M.; Bell, S.M.; Felix, C.; Rashid, Y.; Jafri, H.; Griffiths, P.D.; Neumann, L.M.; Krebs, A.; Reis, A.; Sperling, K.; et al. Mutations in microcephalin cause aberrant regulation of chromosome condensation. Am. J. Hum. Genet. 2004, 75, 261-266. [CrossRef]

31. Lin, S.Y.; Elledge, S.J. Multiple tumor suppressor pathways negatively regulate telomerase. Cell 2003, 113, 881-889. [CrossRef]

32. Jeffers, L.J.; Coull, B.J.; Stack, S.J.; Morrison, C.G. Distinct BRCT domains in Mcph1/Brit1 mediate ionizing radiation-induced focus formation and centrosomal localization. Oncogene 2008, 27, 139-144. [CrossRef]

33. Journiac, N.; Gilabert-Juan, J.; Cipriani, S.; Benit, P.; Liu, X.; Jacquier, S.; Faivre, V.; Delahaye-Duriez, A.; Csaba, Z.; Hourcade, T.; et al. Cell Metabolic Alterations due to Mcph1 Mutation in Microcephaly. Cell Rep. 2020, 31, 107506. [CrossRef]

34. Bilguvar, K.; Ozturk, A.K.; Louvi, A.; Kwan, K.Y.; Choi, M.; Tatli, B.; Yalnizoglu, D.; Tuysuz, B.; Caglayan, A.O.; Gokben, S.; et al. Whole-exome sequencing identifies recessive WDR62 mutations in severe brain malformations. Nature 2010, 467, 207-210. [CrossRef]

35. Jayaraman, D.; Kodani, A.; Gonzalez, D.M.; Mancias, J.D.; Mochida, G.H.; Vagnoni, C.; Johnson, J.; Krogan, N.; Harper, J.W.; Reiter, J.F.; et al. Microcephaly Proteins Wdr62 and Aspm Define a Mother Centriole Complex Regulating Centriole Biogenesis, Apical Complex, and Cell Fate. Neuron 2016, 92, 813-828. [CrossRef]

36. Nicholas, A.K.; Khurshid, M.; Desir, J.; Carvalho, O.P.; Cox, J.J.; Thornton, G.; Kausar, R.; Ansar, M.; Ahmad, W.; Verloes, A.; et al. WDR62 is associated with the spindle pole and is mutated in human microcephaly. Nat. Genet. 2010, 42, 1010-1014. [CrossRef] 
37. Yu, T.W.; Mochida, G.H.; Tischfield, D.J.; Sgaier, S.K.; Flores-Sarnat, L.; Sergi, C.M.; Topcu, M.; McDonald, M.T.; Barry, B.J.; Felie, J.M.; et al. Mutations in WDR62, encoding a centrosome-associated protein, cause microcephaly with simplified gyri and abnormal cortical architecture. Nat. Genet. 2010, 42, 1015-1020. [CrossRef] [PubMed]

38. Bond, J.; Roberts, E.; Springell, K.; Lizarraga, S.B.; Scott, S.; Higgins, J.; Hampshire, D.J.; Morrison, E.E.; Leal, G.F.; Silva, E.O.; et al. A centrosomal mechanism involving CDK5RAP2 and CENPJ controls brain size. Nat. Genet. 2005, 37, 353-355. [CrossRef] [PubMed]

39. Kodani, A.; Yu, T.W.; Johnson, J.R.; Jayaraman, D.; Johnson, T.L.; Al-Gazali, L.; Sztriha, L.; Partlow, J.N.; Kim, H.; Krup, A.L.; et al. Centriolar satellites assemble centrosomal microcephaly proteins to recruit CDK2 and promote centriole duplication. Elife 2015, 4 . [CrossRef]

40. Genin, A.; Desir, J.; Lambert, N.; Biervliet, M.; Van Der Aa, N.; Pierquin, G.; Killian, A.; Tosi, M.; Urbina, M.; Lefort, A.; et al. Kinetochore KMN network gene CASC5 mutated in primary microcephaly. Hum. Mol. Genet. 2012, 21, 5306-5317. [CrossRef]

41. Bond, J.; Roberts, E.; Mochida, G.H.; Hampshire, D.J.; Scott, S.; Askham, J.M.; Springell, K.; Mahadevan, M.; Crow, Y.J.; Markham, A.F.; et al. ASPM is a major determinant of cerebral cortical size. Nat. Genet. 2002, 32, 316-320. [CrossRef]

42. Kumar, A.; Girimaji, S.C.; Duvvari, M.R.; Blanton, S.H. Mutations in STIL, encoding a pericentriolar and centrosomal protein, cause primary microcephaly. Am. J. Hum. Genet. 2009, 84, 286-290. [CrossRef] [PubMed]

43. Tang, C.J.; Lin, S.Y.; Hsu, W.B.; Lin, Y.N.; Wu, C.T.; Lin, Y.C.; Chang, C.W.; Wu, K.S.; Tang, T.K. The human microcephaly protein STIL interacts with CPAP and is required for procentriole formation. EMBO J. 2011, 30, 4790-4804. [CrossRef] [PubMed]

44. Hussain, M.S.; Baig, S.M.; Neumann, S.; Nurnberg, G.; Farooq, M.; Ahmad, I.; Alef, T.; Hennies, H.C.; Technau, M.; Altmuller, J.; et al. A truncating mutation of CEP135 causes primary microcephaly and disturbed centrosomal function. Am. J. Hum. Genet. 2012, 90, 871-878. [CrossRef] [PubMed]

45. Lin, Y.C.; Chang, C.W.; Hsu, W.B.; Tang, C.J.; Lin, Y.N.; Chou, E.J.; Wu, C.T.; Tang, T.K. Human microcephaly protein CEP135 binds to hSAS-6 and CPAP, and is required for centriole assembly. EMBO J. 2013, 32, 1141-1154. [CrossRef]

46. Guernsey, D.L.; Jiang, H.; Hussin, J.; Arnold, M.; Bouyakdan, K.; Perry, S.; Babineau-Sturk, T.; Beis, J.; Dumas, N.; Evans, S.C.; et al. Mutations in centrosomal protein CEP152 in primary microcephaly families linked to MCPH4. Am. J. Hum. Genet. 2010, 87, 40-51. [CrossRef]

47. Yang, Y.J.; Baltus, A.E.; Mathew, R.S.; Murphy, E.A.; Evrony, G.D.; Gonzalez, D.M.; Wang, E.P.; Marshall-Walker, C.A.; Barry, B.J.; Murn, J.; et al. Microcephaly gene links trithorax and REST/NRSF to control neural stem cell proliferation and differentiation Cell 2012, 151, 1097-1112. [CrossRef]

48. Awad, S.; Al-Dosari, M.S.; Al-Yacoub, N.; Colak, D.; Salih, M.A.; Alkuraya, F.S.; Poizat, C. Mutation in PHC1 implicates chromatin remodeling in primary microcephaly pathogenesis. Hum. Mol. Genet. 2013, 22, 2200-2213. [CrossRef]

49. Hussain, M.S.; Baig, S.M.; Neumann, S.; Peche, V.S.; Szczepanski, S.; Nurnberg, G.; Tariq, M.; Jameel, M.; Khan, T.N.; Fatima, A.; et al. CDK6 associates with the centrosome during mitosis and is mutated in a large Pakistani family with primary microcephaly. Hum. Mol. Genet. 2013, 22, 5199-5214. [CrossRef]

50. Mirzaa, G.M.; Vitre, B.; Carpenter, G.; Abramowicz, I.; Gleeson, J.G.; Paciorkowski, A.R.; Cleveland, D.W.; Dobyns, W.B.; O'Driscoll, M. Mutations in CENPE define a novel kinetochore-centromeric mechanism for microcephalic primordial dwarfism. Hum. Genet. 2014, 133, 1023-1039. [CrossRef]

51. Khan, M.A.; Rupp, V.M.; Orpinell, M.; Hussain, M.S.; Altmuller, J.; Steinmetz, M.O.; Enzinger, C.; Thiele, H.; Hohne, W.; Nurnberg, G.; et al. A missense mutation in the PISA domain of HsSAS-6 causes autosomal recessive primary microcephaly in a large consanguineous Pakistani family. Hum. Mol. Genet. 2014, 23, 5940-5949. [CrossRef]

52. Alakbarzade, V.; Hameed, A.; Quek, D.Q.; Chioza, B.A.; Baple, E.L.; Cazenave-Gassiot, A.; Nguyen, L.N.; Wenk, M.R.; Ahmad, A.Q.; Sreekantan-Nair, A.; et al. A partially inactivating mutation in the sodium-dependent lysophosphatidylcholine transporter MFSD2A causes a non-lethal microcephaly syndrome. Nat. Genet. 2015, 47, 814-817. [CrossRef]

53. Guemez-Gamboa, A.; Nguyen, L.N.; Yang, H.; Zaki, M.S.; Kara, M.; Ben-Omran, T.; Akizu, N.; Rosti, R.O.; Rosti, B.; Scott, E.; et al. Inactivating mutations in MFSD2A, required for omega-3 fatty acid transport in brain, cause a lethal microcephaly syndrome. Nat. Genet. 2015, 47, 809-813. [CrossRef] [PubMed]

54. Yamamoto, S.; Jaiswal, M.; Charng, W.L.; Gambin, T.; Karaca, E.; Mirzaa, G.; Wiszniewski, W.; Sandoval, H.; Haelterman, N.A.; Xiong, B.; et al. A drosophila genetic resource of mutants to study mechanisms underlying human genetic diseases. Cell 2014, 159, 200-214. [CrossRef] [PubMed]

55. Harding, B.N.; Moccia, A.; Drunat, S.; Soukarieh, O.; Tubeuf, H.; Chitty, L.S.; Verloes, A.; Gressens, P.; El Ghouzzi, V.; Joriot, S.; et al. Mutations in Citron Kinase Cause Recessive Microlissencephaly with Multinucleated Neurons. Am. J. Hum. Genet. 2016, 99, 511-520. [CrossRef]

56. Li, H.; Bielas, S.L.; Zaki, M.S.; Ismail, S.; Farfara, D.; Um, K.; Rosti, R.O.; Scott, E.C.; Tu, S.; Chi, N.C.; et al. Biallelic Mutations in Citron Kinase Link Mitotic Cytokinesis to Human Primary Microcephaly. Am. J. Hum. Genet. 2016, 99, 501-510. [CrossRef] [PubMed]

57. Kadir, R.; Harel, T.; Markus, B.; Perez, Y.; Bakhrat, A.; Cohen, I.; Volodarsky, M.; Feintsein-Linial, M.; Chervinski, E.; Zlotogora, J.; et al. ALFY-Controlled DVL3 Autophagy Regulates Wnt Signaling, Determining Human Brain Size. PLoS Genet. 2016, 12, e1005919. [CrossRef] 
58. DiStasio, A.; Driver, A.; Sund, K.; Donlin, M.; Muraleedharan, R.M.; Pooya, S.; Kline-Fath, B.; Kaufman, K.M.; Prows, C.A.; Schorry, E.; et al. Copb2 is essential for embryogenesis and hypomorphic mutations cause human microcephaly. Hum. Mol. Genet. 2017, 26, 4836-4848. [CrossRef] [PubMed]

59. Carleton, M.; Mao, M.; Biery, M.; Warrener, P.; Kim, S.; Buser, C.; Marshall, C.G.; Fernandes, C.; Annis, J.; Linsley, P.S. RNA interference-mediated silencing of mitotic kinesin KIF14 disrupts cell cycle progression and induces cytokinesis failure. Mol. Cell Biol. 2006, 26, 3853-3863. [CrossRef]

60. Moawia, A.; Shaheen, R.; Rasool, S.; Waseem, S.S.; Ewida, N.; Budde, B.; Kawalia, A.; Motameny, S.; Khan, K.; Fatima, A.; et al Mutations of KIF14 cause primary microcephaly by impairing cytokinesis. Ann. Neurol. 2017, 82, 562-577. [CrossRef] [PubMed]

61. Martin, C.A.; Murray, J.E.; Carroll, P.; Leitch, A.; Mackenzie, K.J.; Halachev, M.; Fetit, A.E.; Keith, C.; Bicknell, L.S.; Fluteau, A.; et al. Mutations in genes encoding condensin complex proteins cause microcephaly through decatenation failure at mitosis. Genes Dev. 2016, 30, 2158-2172. [CrossRef]

62. Braun, D.A.; Lovric, S.; Schapiro, D.; Schneider, R.; Marquez, J.; Asif, M.; Hussain, M.S.; Daga, A.; Widmeier, E.; Rao, J.; et al. Mutations in multiple components of the nuclear pore complex cause nephrotic syndrome. J. Clin. Investig. 2018, 128, 4313-4328. [CrossRef]

63. Perez, Y.; Bar-Yaacov, R.; Kadir, R.; Wormser, O.; Shelef, I.; Birk, O.S.; Flusser, H.; Birnbaum, R.Y. Mutations in the microtubuleassociated protein MAP11 (C7orf43) cause microcephaly in humans and zebrafish. Brain 2019, 142, 574-585. [CrossRef] [PubMed]

64. Parry, D.A.; Martin, C.A.; Greene, P.; Marsh, J.A.; Genomics England Research, C.; Blyth, M.; Cox, H.; Donnelly, D.; Greenhalgh, L.; Greville-Heygate, S.; et al. Heterozygous lamin B1 and lamin B2 variants cause primary microcephaly and define a novel laminopathy. Genet. Med. 2021, 23, 408-414. [CrossRef] [PubMed]

65. Farooq, M.; Lindbaek, L.; Krogh, N.; Doganli, C.; Keller, C.; Monnich, M.; Goncalves, A.B.; Sakthivel, S.; Mang, Y.; Fatima, A.; et al. RRP7A links primary microcephaly to dysfunction of ribosome biogenesis, resorption of primary cilia, and neurogenesis. Nat. Commun. 2020, 11, 5816. [CrossRef] [PubMed]

66. Waseem, S.S.; Moawia, A.; Budde, B.; Tariq, M.; Khan, A.; Ali, Z.; Khan, S.; Iqbal, M.; Malik, N.A.; Haque, S.U.; et al. A Homozygous AKNA Frameshift Variant Is Associated with Microcephaly in a Pakistani Family. Genes 2021, 12, 1494. [CrossRef]

67. Neitzel, H.; Neumann, L.M.; Schindler, D.; Wirges, A.; Tonnies, H.; Trimborn, M.; Krebsova, A.; Richter, R.; Sperling, K. Premature chromosome condensation in humans associated with microcephaly and mental retardation: A novel autosomal recessive condition. Am. J. Hum. Genet. 2002, 70, 1015-1022. [CrossRef]

68. Tommerup, N.; Mortensen, E.; Nielsen, M.H.; Wegner, R.D.; Schindler, D.; Mikkelsen, M. Chromosomal breakage, endomitosis, endoreduplication, and hypersensitivity toward radiomimetric and alkylating agents: A possible new autosomal recessive mutation in a girl with craniosynostosis and microcephaly. Hum. Genet. 1993, 92, 339-346. [CrossRef]

69. Farooq, M.; Baig, S.; Tommerup, N.; Kjaer, K.W. Craniosynostosis-microcephaly with chromosomal breakage and other abnormalities is caused by a truncating $\mathrm{MCPH} 1$ mutation and is allelic to premature chromosomal condensation syndrome and primary autosomal recessive microcephaly type 1. Am. J. Med. Genet. A 2010, 152A, 495-497. [CrossRef]

70. Phillips, E.R.; McKinnon, P.J. DNA double-strand break repair and development. Oncogene 2007, 26, 7799-7808. [CrossRef]

71. Alderton, G.K.; Galbiati, L.; Griffith, E.; Surinya, K.H.; Neitzel, H.; Jackson, A.P.; Jeggo, P.A.; O'Driscoll, M. Regulation of mitotic entry by microcephalin and its overlap with ATR signalling. Nat. Cell Biol. 2006, 8, 725-733. [CrossRef]

72. Alcantara, D.; O’Driscoll, M. Congenital microcephaly. Am. J. Med. Genet. C Semin. Med. Genet. 2014, 166C, 124-139. [CrossRef] [PubMed]

73. Jackson, A.P.; McHale, D.P.; Campbell, D.A.; Jafri, H.; Rashid, Y.; Mannan, J.; Karbani, G.; Corry, P.; Levene, M.I.; Mueller, R.F.; et al. Primary autosomal recessive microcephaly (MCPH1) maps to chromosome 8p22-pter. Am. J. Hum. Genet. 1998, 63, 541-546. [CrossRef] [PubMed]

74. Darvish, H.; Esmaeeli-Nieh, S.; Monajemi, G.B.; Mohseni, M.; Ghasemi-Firouzabadi, S.; Abedini, S.S.; Bahman, I.; Jamali, P.; Azimi, S.; Mojahedi, F.; et al. A clinical and molecular genetic study of 112 Iranian families with primary microcephaly. J. Med. Genet. 2010, 47, 823-828. [CrossRef]

75. Lin, S.Y.; Rai, R.; Li, K.; Xu, Z.X.; Elledge, S.J. BRIT1/MCPH1 is a DNA damage responsive protein that regulates the Brca1-Chk1 pathway, implicating checkpoint dysfunction in microcephaly. Proc. Natl. Acad. Sci. USA 2005, 102, 15105-15109. [CrossRef] [PubMed]

76. Pulvers, J.N.; Journiac, N.; Arai, Y.; Nardelli, J. MCPH1: A window into brain development and evolution. Front. Cell Neurosci. 2015, 9, 92. [CrossRef]

77. Liu, X.; Zhou, Z.W.; Wang, Z.Q. The DNA damage response molecule MCPH1 in brain development and beyond. Acta Biochim. Biophys. Sin. (Shanghai) 2016, 48, 678-685. [CrossRef]

78. Trimborn, M.; Richter, R.; Sternberg, N.; Gavvovidis, I.; Schindler, D.; Jackson, A.P.; Prott, E.C.; Sperling, K.; Gillessen-Kaesbach, G.; Neitzel, H. The first missense alteration in the MCPH1 gene causes autosomal recessive microcephaly with an extremely mild cellular and clinical phenotype. Hum. Mutat. 2005, 26, 496. [CrossRef]

79. Ghani-Kakhki, M.; Robinson, P.N.; Morlot, S.; Mitter, D.; Trimborn, M.; Albrecht, B.; Varon, R.; Sperling, K.; Neitzel, H. Two Missense Mutations in the Primary Autosomal Recessive Microcephaly Gene MCPH1 Disrupt the Function of the Highly Conserved N-Terminal BRCT Domain of Microcephalin. Mol. Syndromol. 2012, 3, 6-13. [CrossRef]

80. Lin, S.Y.; Liang, Y.; Li, K. Multiple roles of BRIT1/MCPH1 in DNA damage response, DNA repair, and cancer suppression. Yonsei Med. J. 2010, 51, 295-301. [CrossRef] 
81. Gruber, R.; Zhou, Z.; Sukchev, M.; Joerss, T.; Frappart, P.O.; Wang, Z.Q. MCPH1 regulates the neuroprogenitor division mode by coupling the centrosomal cycle with mitotic entry through the Chk1-Cdc25 pathway. Nat. Cell Biol. 2011, 13, 1325-1334. [CrossRef] [PubMed]

82. Gavvovidis, I.; Rost, I.; Trimborn, M.; Kaiser, F.J.; Purps, J.; Wiek, C.; Hanenberg, H.; Neitzel, H.; Schindler, D. A novel MCPH1 isoform complements the defective chromosome condensation of human MCPH1-deficient cells. PLoS ONE 2012, 7, e40387. [CrossRef] [PubMed]

83. Glover, J.N.; Williams, R.S.; Lee, M.S. Interactions between BRCT repeats and phosphoproteins: Tangled up in two. Trends Biochem. Sci. 2004, 29, 579-585. [CrossRef] [PubMed]

84. Huyton, T.; Bates, P.A.; Zhang, X.; Sternberg, M.J.; Freemont, P.S. The BRCA1 C-terminal domain: Structure and function. Mutat Res. 2000, 460, 319-332. [CrossRef]

85. Derbyshire, D.J.; Basu, B.P.; Serpell, L.C.; Joo, W.S.; Date, T.; Iwabuchi, K.; Doherty, A.J. Crystal structure of human 53BP1 BRCT domains bound to p53 tumour suppressor. EMBO J. 2002, 21, 3863-3872. [CrossRef]

86. Mesquita, R.D.; Woods, N.T.; Seabra-Junior, E.S.; Monteiro, A.N. Tandem BRCT Domains: DNA's Praetorian Guard. Genes Cancer 2010, 1, 1140-1146. [CrossRef]

87. Williams, R.S.; Bernstein, N.; Lee, M.S.; Rakovszky, M.L.; Cui, D.; Green, R.; Weinfeld, M.; Glover, J.N. Structural basis for phosphorylation-dependent signaling in the DNA-damage response. Biochem. Cell Biol. 2005, 83, 721-727. [CrossRef]

88. Woods, N.T.; Mesquita, R.D.; Sweet, M.; Carvalho, M.A.; Li, X.; Liu, Y.; Nguyen, H.; Thomas, C.E.; Iversen, E.S., Jr.; Marsillac, S.; et al. Charting the landscape of tandem BRCT domain-mediated protein interactions. Sci. Signal. 2012, 5, rs6. [CrossRef]

89. Li, M.; Lu, L.Y.; Yang, C.Y.; Wang, S.; Yu, X. The FHA and BRCT domains recognize ADP-ribosylation during DNA damage response. Genes Dev. 2013, 27, 1752-1768. [CrossRef]

90. Wood, J.L.; Liang, Y.; Li, K.; Chen, J. Microcephalin/MCPH1 associates with the Condensin II complex to function in homologous recombination repair. J. Biol. Chem. 2008, 283, 29586-29592. [CrossRef]

91. Liu, X.; Schneble-Lohnert, N.; Kristofova, M.; Qing, X.; Labisch, J.; Hofmann, S.; Ehrenberg, S.; Sannai, M.; Jorss, T.; Ori, A.; et al. The N-terminal BRCT domain determines MCPH1 function in brain development and fertility. Cell Death Dis. 2021, $12,143$. [CrossRef]

92. Kristofova, M.; Wang, Z.Q. MCPH1, beyond its role deciding the brain size. Aging (Albany NY) 2021, 13, 23437-23439. [CrossRef]

93. Meyer, S.K.; Dunn, M.; Vidler, D.S.; Porter, A.; Blain, P.G.; Jowsey, P.A. Phosphorylation of MCPH1 isoforms during mitosis followed by isoform-specific degradation by APC/C-CDH1. FASEB J. 2019, 33, 2796-2808. [CrossRef] [PubMed]

94. Zhong, X.; Pfeifer, G.P.; Xu, X. Microcephalin encodes a centrosomal protein. Cell Cycle 2006, 5, 457-458. [CrossRef]

95. Tibelius, A.; Marhold, J.; Zentgraf, H.; Heilig, C.E.; Neitzel, H.; Ducommun, B.; Rauch, A.; Ho, A.D.; Bartek, J.; Kramer, A. Microcephalin and pericentrin regulate mitotic entry via centrosome-associated Chk1. J. Cell Biol. 2009, 185, 1149-1157. [CrossRef] [PubMed]

96. Hainline, S.G.; Rickmyre, J.L.; Neitzel, L.R.; Lee, L.A.; Lee, E. The Drosophila MCPH1-B isoform is a substrate of the APCCdh1 E3 ubiquitin ligase complex. Biol. Open 2014, 3, 669-676. [CrossRef]

97. Brown, J.A.; Bourke, E.; Liptrot, C.; Dockery, P.; Morrison, C.G. MCPH1/BRIT1 limits ionizing radiation-induced centrosome amplification. Oncogene 2010, 29, 5537-5544. [CrossRef] [PubMed]

98. Denu, R.A.; Burkard, M.E. Analysis of the "centrosome-ome" identifies MCPH1 deletion as a cause of centrosome amplification in human cancer. Sci. Rep. 2020, 10, 11921. [CrossRef]

99. Mai, L.; Yi, F.; Gou, X.; Zhang, J.; Wang, C.; Liu, G.; Bu, Y.; Yuan, C.; Deng, L.; Song, F. The overexpression of MCPH1 inhibits cell growth through regulating cell cycle-related proteins and activating cytochrome c-caspase 3 signaling in cervical cancer. Mol. Cell Biochem. 2014, 392, 95-107. [CrossRef]

100. Zhou, L.; Bai, Y.; Li, Y.; Liu, X.; Tan, T.; Meng, S.; He, W.; Wu, X.; Dong, Z. Overexpression of MCPH1 inhibits uncontrolled cell growth by promoting cell apoptosis and arresting the cell cycle in S and G2/M phase in lung cancer cells. Oncol. Lett. 2016, 11, 365-372. [CrossRef]

101. Xu, X.; Lee, J.; Stern, D.F. Microcephalin is a DNA damage response protein involved in regulation of CHK1 and BRCA1. J. Biol. Chem. 2004, 279, 34091-34094. [CrossRef]

102. Yamashita, D.; Shintomi, K.; Ono, T.; Gavvovidis, I.; Schindler, D.; Neitzel, H.; Trimborn, M.; Hirano, T. MCPH1 regulates chromosome condensation and shaping as a composite modulator of condensin II. J. Cell Biol. 2011, 194, 841-854. [CrossRef]

103. Wu, X.; Mondal, G.; Wang, X.; Wu, J.; Yang, L.; Pankratz, V.S.; Rowley, M.; Couch, F.J. Microcephalin regulates BRCA2 and Rad51-associated DNA double-strand break repair. Cancer Res. 2009, 69, 5531-5536. [CrossRef]

104. Wood, J.L.; Singh, N.; Mer, G.; Chen, J. MCPH1 functions in an H2AX-dependent but MDC1-independent pathway in response to DNA damage. J. Biol. Chem. 2007, 282, 35416-35423. [CrossRef] [PubMed]

105. Liang, Y.; Gao, H.; Lin, S.Y.; Peng, G.; Huang, X.; Zhang, P.; Goss, J.A.; Brunicardi, F.C.; Multani, A.S.; Chang, S.; et al. BRIT1/MCPH1 is essential for mitotic and meiotic recombination DNA repair and maintaining genomic stability in mice. PLoS Genet. 2010, 6, e1000826. [CrossRef]

106. Peng, G.; Yim, E.K.; Dai, H.; Jackson, A.P.; Burgt, I.; Pan, M.R.; Hu, R.; Li, K.; Lin, S.Y. BRIT1/MCPH1 links chromatin remodelling to DNA damage response. Nat. Cell Biol. 2009, 11, 865-872. [CrossRef] 
107. Kim, H.; Lee, O.H.; Xin, H.; Chen, L.Y.; Qin, J.; Chae, H.K.; Lin, S.Y.; Safari, A.; Liu, D.; Songyang, Z. TRF2 functions as a protein hub and regulates telomere maintenance by recognizing specific peptide motifs. Nat. Struct Mol. Biol. 2009, 16, 372-379. [CrossRef]

108. Cicconi, A.; Rai, R.; Xiong, X.; Broton, C.; Al-Hiyasat, A.; Hu, C.; Dong, S.; Sun, W.; Garbarino, J.; Bindra, R.S.; et al. Microcephalin 1/BRIT1-TRF2 interaction promotes telomere replication and repair, linking telomere dysfunction to primary microcephaly. Nat. Commun. 2020, 11, 5861. [CrossRef] [PubMed]

109. Shi, L.; Li, M.; Su, B. MCPH1/BRIT1 represses transcription of the human telomerase reverse transcriptase gene. Gene 2012, 495, 1-9. [CrossRef]

110. Yang, S.Z.; Lin, F.T.; Lin, W.C. MCPH1/BRIT1 cooperates with E2F1 in the activation of checkpoint, DNA repair and apoptosis. EMBO Rep. 2008, 9, 907-915. [CrossRef] [PubMed]

111. Trimborn, M.; Ghani, M.; Walther, D.J.; Dopatka, M.; Dutrannoy, V.; Busche, A.; Meyer, F.; Nowak, S.; Nowak, J.; Zabel, C.; et al Establishment of a mouse model with misregulated chromosome condensation due to defective Mcph1 function. PLoS ONE 2010, 5, e9242. [CrossRef] [PubMed]

112. Liu, X.; Zong, W.; Li, T.; Wang, Y.; Xu, X.; Zhou, Z.W.; Wang, Z.Q. The E3 ubiquitin ligase APC/C(C)(dh1) degrades MCPH1 after MCPH1-betaTrCP2-Cdc25A-mediated mitotic entry to ensure neurogenesis. EMBO J. 2017, 36, 3666-3681. [CrossRef] [PubMed]

113. Singh, N.; Wiltshire, T.D.; Thompson, J.R.; Mer, G.; Couch, F.J. Molecular basis for the association of microcephalin (MCPH1) protein with the cell division cycle protein 27 (Cdc27) subunit of the anaphase-promoting complex. J. Biol. Chem. 2012, 287, 2854-2862. [CrossRef]

114. Houlard, M.; Cutts, E.E.; Shamim, M.S.; Godwin, J.; Weisz, D.; Presser Aiden, A.; Lieberman-Aiden, E.; Schermelleh, L.; Nasmyth, K.; Vannini, A. MCPH1 inhibits condensin II during interphase by regulating its SMC2-kleisin interface. Elife 2021, 10. [CrossRef] [PubMed]

115. Green, L.C.; Kalitsis, P.; Chang, T.M.; Cipetic, M.; Kim, J.H.; Marshall, O.; Turnbull, L.; Whitchurch, C.B.; Vagnarelli, P.; Samejima, K.; et al. Contrasting roles of condensin I and condensin II in mitotic chromosome formation. J. Cell Sci. 2012, 125, 1591-1604. [CrossRef]

116. Vincent, E.E.; Sergushichev, A.; Griss, T.; Gingras, M.C.; Samborska, B.; Ntimbane, T.; Coelho, P.P.; Blagih, J.; Raissi, T.C.; Choiniere, L.; et al. Mitochondrial Phosphoenolpyruvate Carboxykinase Regulates Metabolic Adaptation and Enables Glucose-Independent Tumor Growth. Mol. Cell 2015, 60, 195-207. [CrossRef]

117. Lange, C.; Turrero Garcia, M.; Decimo, I.; Bifari, F.; Eelen, G.; Quaegebeur, A.; Boon, R.; Zhao, H.; Boeckx, B.; Chang, J.; et al Relief of hypoxia by angiogenesis promotes neural stem cell differentiation by targeting glycolysis. EMBO J. 2016, 35, 924-941. [CrossRef]

118. Asimakopoulou, A.; Fulop, A.; Borkham-Kamphorst, E.; de Leur, E.V.; Gassler, N.; Berger, T.; Beine, B.; Meyer, H.E.; Mak, T.W.; Hopf, C.; et al. Altered mitochondrial and peroxisomal integrity in lipocalin-2-deficient mice with hepatic steatosis. Biochim. Biophys. Acta Mol. Basis Dis. 2017, 1863, 2093-2110. [CrossRef]

119. Hans, F.; Dimitrov, S. Histone H3 phosphorylation and cell division. Oncogene 2001, 20, 3021-3027. [CrossRef]

120. Zhou, Z.W.; Tapias, A.; Bruhn, C.; Gruber, R.; Sukchev, M.; Wang, Z.Q. DNA damage response in microcephaly development of MCPH1 mouse model. DNA Repair. (Amst) 2013, 12, 645-655. [CrossRef]

121. Gavvovidis, I.; Pohlmann, C.; Marchal, J.A.; Stumm, M.; Yamashita, D.; Hirano, T.; Schindler, D.; Neitzel, H.; Trimborn, M. MCPH1 patient cells exhibit delayed release from DNA damage-induced G2/M checkpoint arrest. Cell Cycle 2010, 9, 4893-4899. [CrossRef] [PubMed]

122. Chen, J.; Ingham, N.; Clare, S.; Raisen, C.; Vancollie, V.E.; Ismail, O.; McIntyre, R.E.; Tsang, S.H.; Mahajan, V.B.; Dougan, G.; et al Mcph1-deficient mice reveal a role for MCPH1 in otitis media. PLoS ONE 2013, 8, e58156. [CrossRef]

123. Woods, R.P.; Freimer, N.B.; De Young, J.A.; Fears, S.C.; Sicotte, N.L.; Service, S.K.; Valentino, D.J.; Toga, A.W.; Mazziotta, J.C. Normal variants of Microcephalin and ASPM do not account for brain size variability. Hum. Mol. Genet. 2006, 15, $2025-2029$. [CrossRef] [PubMed]

124. Dobson-Stone, C.; Gatt, J.M.; Kuan, S.A.; Grieve, S.M.; Gordon, E.; Williams, L.M.; Schofield, P.R. Investigation of MCPH1 G37995C and ASPM A44871G polymorphisms and brain size in a healthy cohort. Neuroimage 2007, 37, 394-400. [CrossRef]

125. Rai, R.; Dai, H.; Multani, A.S.; Li, K.; Chin, K.; Gray, J.; Lahad, J.P.; Liang, J.; Mills, G.B.; Meric-Bernstam, F.; et al. BRIT1 regulates early DNA damage response, chromosomal integrity, and cancer. Cancer Cell 2006, 10, 145-157. [CrossRef]

126. Mantere, T.; Winqvist, R.; Kauppila, S.; Grip, M.; Jukkola-Vuorinen, A.; Tervasmaki, A.; Rapakko, K.; Pylkas, K. Targeted Next-Generation Sequencing Identifies a Recurrent Mutation in MCPH1 Associating with Hereditary Breast Cancer Susceptibility. PLoS Genet. 2016, 12, e1005816. [CrossRef] [PubMed]

127. Liang, Y.; Gao, H.; Lin, S.Y.; Goss, J.A.; Du, C.; Li, K. Mcph1/Brit1 deficiency promotes genomic instability and tumor formation in a mouse model. Oncogene 2015, 34, 4368-4378. [CrossRef]

128. Shi, L.; Luo, X.; Jiang, J.; Chen, Y.; Liu, C.; Hu, T.; Li, M.; Lin, Q.; Li, Y.; Huang, J.; et al. Transgenic rhesus monkeys carrying the human MCPH1 gene copies show human-like neoteny of brain development. Natl. Sci. Rev. 2019, 6, 480-493. [CrossRef] 